\title{
Induction of apoptosis in imatinib sensitive and resistant chronic myeloid leukemia cells by efficient disruption of bcr-abl oncogene with zinc finger nucleases
}

Ningshu Huang ${ }^{1 \dagger}$, Zhenglan Huang ${ }^{1 \dagger}$, Miao Gao $^{2}$, Zhenhong Luo ${ }^{1}$, Fangzhu Zhou ${ }^{1}$, Lin Liu ${ }^{3}$, Qing Xiao ${ }^{3}$, Xin Wang ${ }^{3}$ and Wenli Feng ${ }^{1 *}$

\begin{abstract}
Background: The bcr-abl fusion gene is the pathological origin of chronic myeloid leukemia (CML) and plays a critical role in the resistance of imatinib. Thus, bcr-abl disruption-based novel therapeutic strategy may warrant exploration. In our study, we were surprised to find that the characteristics of bcr-abl sequences met the design requirements of zinc finger nucleases (ZFNs).

Methods: We constructed the ZFNs targeting bcr-abl with high specificity through simple modular assembly approach. Western blotting was conducted to detect the expression of BCR-ABL and phosphorylation of its downstream STAT5, ERK and CRKL in CML cells. CCK8 assay, colony-forming assay and flow cytometry (FCM) were used to evaluate the effect of the ZFNs on the viablity and apoptosis of CML cells and CML CD34 ${ }^{+}$cells. Moreover, mice model was used to determine the ability of ZFNs in disrupting the leukemogenesis of bcr-abl in vivo.
\end{abstract}

Results: The ZFNs skillfully mediated 8-base Notl enzyme cutting site addition in bcr-abl gene of imatinib sensitive and resistant CML cells by homology-directed repair (HDR), which led to a stop codon and terminated the translation of BCR-ABL protein. As expected, the disruption of bcr-abl gene induced cell apoptosis and inhibited cell proliferation. Notably, we obtained similar result in $\mathrm{CD} 34^{+}$cells from CML patients. Moreover, the ZFNs significantly reduced the oncogenicity of CML cells in mice.

Conclusion: These results reveal that the bcr-abl gene disruption based on ZFNs may provide a treatment choice for imatinib resistant or intolerant CML patients.

Keywords: Chronic myeloid leukemia, Bcr-abl, Zinc finger nucleases, Homology-directed repair, Oncogenicity

\section{Background}

The bcr-abl oncogene, a fusion of bcr and c-abl sequences, results from the $\mathrm{t}(9 ; 22)(\mathrm{q} 34 ; \mathrm{q} 11)$ chromosomal translocation and encodes BCR-ABL fusion protein with elevated tyrosine kinase activity [1-4]. As a oncogenic kinase, BCR-ABL abnormally activates several downstream

\footnotetext{
* Correspondence: fengwlcamu@sina.com

${ }^{\dagger}$ Equal contributors

'Department of Clinical Hematology, Key Laboratory of Laboratory Medical Diagnostics Designated by the Ministry of Education, Chongqing Medical University, No.1, Yixueyuan Road, Chongqing 400016, People's Republic of China

Full list of author information is available at the end of the article
}

signaling pathways including RAS-MAPK, STAT5 and CRKL, which contribute to inhibition of apoptosis and induction of malignant transformation [5]. The firstgeneration tyrosine kinase inhibitor (TKI) imatinib, as the first-line treatment of CML, inhibits the phosphorylation of BCR-ABL and the activation of multiple downstream substrates $[1,6]$. However, more than $25 \%$ of CML patients develop imatinib intolerance or resistance and $50 \%$ of these patients harbor bcr-abl point mutations [7, 8]. The second and third generation of TKIs have different sensitivities and potencies to the mutations $[6,9]$, but these drugs require long-term medication which enhance 
economic burden and adverse drug events [8, 10-13]. Consequently, the resistance to TKIs is still the primary problem need to be solved in CML treatment.

Ultimately, the bcr-abl gene is the underlying cause of the CML pathogenesis and TKI-resistance. Therefore, in theory, a method to destroy bcr-abl gene will fundamentally solve the problem of CML onset and drug resistance. The technique known as 'genome editing' such as zinc finger nucleases (ZFNs) [14-16], transcription activatorlike effector nucleases (TALENs) [17-19] and clustered regulatory interspaced short palindromic repeats (CRISPR) / Cas9 [20, 21] is opening the possibility of disrupting bcr-abl oncogene. Analysis of the bcr-abl sequence analysis shows that it is ideal for the construction of ZFNs. ZFNs are generated by fusing the sequence-specific DNA-binding domain to endonuclease domain of FokI [22, 23]. DNA-binding domain is composed of $\mathrm{C} 2 \mathrm{H} 2$ zinc-finger proteins (ZFPs). Each finger recognizes 3-base pairs of DNA [24, 25] and has the highest affinity to the 5'-GNN-3' nucleotide triplet [26]. Three to four zinc-finger domains linked together in tandem to constitute each of ZFN dimers and bind to 18-bp to 24-bp targeting DNA, such a long site is rarer cleavage targets even in complex genomes [27]. In the coding sequence of bcr-abl, there are 15 sites containing the best binding $5^{\prime}-\mathrm{GNN}-3^{\prime}$ sequence fit to generate 'three fingers ZFNs' and among these sites even have 3 sites suitable to construct 'four fingers ZFNs'. The design of ZFNs aim at these sites can effectively and specifically modify bcr-abl and also reduce the off-target cleavage. Therefore, ZFNs are the preferred technology for bcr-abl gene editing. FokI domain, a nonspecific restriction enzyme, cuts the DNA sequence identified by the ZFPs and introduces a DNA double strand break (DSB) [22]. Off-target effects and cellular toxicity by ZFNs can be induced by the homodimers formation of wild-type FokI [27-29]. To address this problem, FokI nuclease variants have been used to eliminate the unwanted homodimers and cleave DNA only as a heterodimer pair [28-30].

The lesion of DSB by ZFNs can be repaired by nonhomologous end joining (NHEJ) or homology-directed repair (HDR) [27, 31]. NHEJ is a process that the lesion can be repaired by directly ligating the two broken ends of DSB which does not need a repair template. It can be accurate but repairing DSB with nucleotide mismatches eventually results in insertion or deletion mutations around the break site [32]. However, when a homologous donor DNA template is provided with ZFNs, the rate of HDR at the lesion observably increase $[27,33,34]$. HDR transfers information from homologous donor DNA to the breaks which can achieve introducing precise changes to defined genomic sequences [35]. Following this principle, HDR allows researchers to take advantage of a suitably designed exogenous DNA template to alter or replace the mutated gene directly.

Considering the significant role of bcr-abl in the pathogenesis of CML and resistance of TKI, and importantly, the sequence of bcr-abl is highly suitable for ZFNs construction, we designed ZFNs to targeted disrupt the bcr-abl gene by modular assembly. The modular assembly is the easiest and high-efficiently designed approach for making active ZFNs [36] and has designed a number of active ZFNs to modify the endogenous gene in higher eukaryotic cells [37]. This method generates candidate ZFPs based on identifying fingers to bind a component triplet and these fingers are then linked to target the corresponding sequence. As we know, the bcr-abl containing the first exon of bcr which includes a coiled-coil domain, Tyr177, SH2 binding domain and a serine/ threonine kinase domain, is crucial to induce chronicphase CML [36, 38-41]. Moreover, we found that the sequences of bcr exon1 containing the 5'-GNNG NNGNNGNN-3' consensus sequence which fit the characteristics of creating an active ZFNs by modular assembly [26]. When the ZFNs targeting the exon1 of bcr-abl and the donor DNA sequence containing a Not $\mathrm{I}$ enzyme cutting site composed of 8-base were codelivered into cells, these 8-base were integrated into the exon1 of bcr-abl sequence by HDR and generated a stop codon in the downstream of ZFNs cleavage site, ultimately leading to premature termination of BCR-ABL translation. In view of the above findings, we designed a bcr-abl gene editing approach based on ZFNs. Here, we investigated whether our ZFNs can effectively cut the bcr-abl gene and decrease the expression of BCR-ABL and its downstream molecules. In addition, we evaluated the effect of our ZFNs on inhibiting the malignant proliferation and inducing apoptosis of CML CD34 $4^{+}$cell. Importantly, in vivo experiments were made to determine whether the bcr-abl oncogenicity was also destructed by the ZFNs.

\section{Methods}

\section{Cell lines and cell culture}

K562 (Cell Bank of Shanghai Institute of Cell Biology, Chinese Academy of Sciences) and K562/G01 cells were maintained in RPMI 1640 (Gibco, USA) containing 10\% fetal bovine serum (Gibco, USA). The resistant cell line, K562/G01, was screened from K562 by culturing with successively increased concentrations of imatinib for several months [42]. For 32D cells, additional $1 \mathrm{ng} / \mathrm{ml}$ of murine IL-3 (PeproTech, USA) was supplemented. $293 \mathrm{~T}$ and HepG2 cells were cultured in Dulbecco's modified Eagle medium (DMEM) contained of 10\% fetal bovine serum. All cells were cultured at $37{ }^{\circ} \mathrm{C}$ in a $5 \%$ $\mathrm{CO}_{2}$ humidified incubator. 


\section{Nucleofection}

ZFNs were transfeced using the Amaxa Nucleofector II device together with the cell line nucleofector kit $\mathrm{V}$ or human $\mathrm{CD}^{+} 4^{+}$cells nucleofector kit (Lonza, Basel, Switzerland). $1 \times 10^{6}$ cells were collected, resuspended in $100 \mu \mathrm{l}$ of the pre-mixed nucleofector solution with DNA plasmids and nucleofected with the program T016 for $\mathrm{K} 562$ and K562/G01, E-032 for 32D, and U-008 for $\mathrm{CD}_{34}{ }^{+}$cells. After nucleofection, the cells were immediatly resuspended in $500 \mu \mathrm{l}$ pre-warmed medium and maintained in a 12-well plate.

\section{Constructs}

ZFP-L and ZFP-R were designed and assembled as described. FokI plasmids, containing the Sharkey mutations and the ELD/KKR obligate heterodimer mutations, were obtained from Addgene (FokI-L: plasmid \#37198; FokIR: plasmid \#37199) containing the Sharkey mutations and the ELD/KKR obligate heterodimer mutations. Assembled ZFNs were cloned into pAdTrack-CMV termed ZFN-L and ZFN-R. FLAG tag was added to the Nterminal of pAdTrack-CMV. The homology arms in the donor, containing left arm and right arm, were amplified through PCR from human and mouse genomic DNA. The left arm (sense: 5'-CGGGGTACCCAGCGATGGG GCTTCCGGCG-3', antisense: 5'-AAGGAAAAAAGC GGCCGCGGGTTCAACTCGGCGTCCTCGTAGTCG-3') and right arm (sense: 5'-AAGGAAAAAAGCGGCCGC CCGCTTCCTGAAGGACAACCTGATCG-3', antisense: 5'-GCTCTAGAGCCAGGATTCCCGACAGGACCCATT TTC-3') were inserted into pAdTrack-CMV vector at $K p n \mathrm{I}, \mathrm{NotI}$, and $\mathrm{Xba \textrm {I }}$ site to generate the donor plasmid.

The amino acid sequences of ZFP-L and ZFP-R were as follows respectively:

ZFP-L: 5' LEPGEKPYKCPECGKSFSDCRDLARHQRT HTGEKPYKCPECGKSFSDPGNLVRHQRTHTGEKPYK CPECGKSFSDPGALVRHQRTHTGEKPYKCPECGKSFSD CRDLARHQRTHTGKKTS 3'.

ZFP-R: 5' LEPGEKPYKCPECGKSFSRSDNLVRHQRT HTGEKPYKCPECGKSFSDCRDLARHQRTHTGEKPYK CPECGKSFSDPGNLVRHQRTHTGEKPYKCPECGKS FSRSDNLVRHQRTHTGKKTS 3'.

The binding sites of ZFN-L and ZFN-R to bcr-abl were as follows respectively: 5' - GGCGTCGACGGC GAGGACGCCGAG-3'.

5'-CTCGGCGTCCTCGCCGTCGACGCC-3'.

The cleavage site of ZFNs is 5'-GACTAC-3'.

\section{T7E1 assay}

Genomic DNA was extracted from the cells treated with ZFNs using the Hipure Tissue DNA Mini Kit (Magen, China). PCR amplification of the region surrounding the ZFNs target site was performed using the PrimeSTAR HS DNA Polymeras (TaKaRa) and 100 ng of genomic
DNA as template with primer 5'-GACGCCGAG AAGCCCTTC-3'and 5'-AATCCTCAAAACTCCGGGG G -3 '. The PCR products were melted and annealed to form heteroduplex DNA. The annealed DNA was treated with T7 endonuclease 1 (New England BioLabs) for $15 \mathrm{~min}$ at $37{ }^{\circ} \mathrm{C}$ [37]. Data was analyzed by agarose gel electrophoresis. Ratio of cleaved to uncleaved products was calculated as a measure of frequency of gene disruption and the mutation was also analyzed using next-generation sequencing, as described [43].

\section{Detection of HDR events}

K562 cells were transfected with ZFN-L/R and donor vector. After treated for $48 \mathrm{~h}$, the genomic DNA of cells was extracted and then amplified by PCR as described above. Donor DNA was characterized by the NotI site they carried, so the PCR products were analyzed by NotI enzyme digestion with the following reaction system: $1 \mu \mathrm{l}$ NotI, $2 \mu \mathrm{l}$ $10 \times \mathrm{H}$ Buffer, $2 \mu \mathrm{l}$ 0.1\%BSA, $2 \mu \mathrm{l} 0.1 \%$ Triton X-100, $1 \mu \mathrm{g}$ DNA and $d_{d H_{2}} \mathrm{O}$ up to $20 \mu \mathrm{l}$ at $37^{\circ} \mathrm{C}$. These results were measured by agarose gel electrophoresis.

\section{Western blotting}

Western blotting assay was performed as previously described [44]. The primary antibodies were as follows: anti-BCR-ABL, anti-Phospho-BCR-ABL, anti-c-Abl, antiPhospho-STAT5, anti-STAT5, anti-ERK 1/2, anti-Caspase3 and anti-PARP were all purchased from Cell Signaling Technology (USA), used at 1:1000 dilution. Anti-FLAG monoclonal antibody (Sigma, USA) was added at a concentration of 1:500 and anti- $\beta$-Actin (Zhong Shan Jin Qiao, China) antibody was used at 1:1000 dilution. The expression quantity of each protein was normalized against the $\beta$-Actin protein expression using image software.

\section{CCK-8 assay}

The treated cells were plated into 96-well plates at a density of 2000 cells per well with $100 \mu$ l RPMI 1640 containing $15 \%$ fetal bovine serum and cultured at $37{ }^{\circ} \mathrm{C}$ in a $5 \% \mathrm{CO}_{2}$ humidified incubator. To prevent the medium evaporation, we added $100 \mu \mathrm{l}$ PBS to the wells surrounding the sample wells. At indicated time $10 \mu \mathrm{l}$ of CCK-8 (Solarbo,China) was added to each well then incubated at $37{ }^{\circ} \mathrm{C}$ for $3 \mathrm{~h}$. Then the absorbance at $450 \mathrm{~nm}$ was measured by micro-plate reader (Eon, BioTeck, USA). Each assay was repeated for five times.

\section{Colony-forming assay}

Treated cells were collected and plated (300 cells/well) in 24-well plates with methylcellulose for assessing the colony-forming ability. The number of colonies were counted at 7-14 days later, using an inverted microscope. The colony formation assay were performed for five times. 


\section{Immunofluorescence assay}

Cells were collected for immunofluoresence assay, washed 3 times by PBS and coated on slides. The cells were fixed in $4 \%$ paraformaldehyde, permeabilized with $0.1 \%$ Triton X-100 at $37{ }^{\circ} \mathrm{C}$, blocked in $1 \%$ BSA with $5 \%$ goat serum and incubated primary antibody at $4^{\circ} \mathrm{C}$ overnight. Next, the cells were incubated with fluorochromeconjugated secondary antibody (1:200, Zhong Shan Jin Qiao, China) in a dark room at $37{ }^{\circ} \mathrm{C}$ for $1 \mathrm{~h}$. Lastly, the nucleus was stained with DAPI.

\section{Samples and hematopoietic stem cell isolation}

Samples were obtained from CML patients, who were initially diagnosed with CML and had not undergone any chemotherapy (Table 1), or anemia individuals from the first affiliated hospital of Chongqing Medical University or the second affiliated hospital of Chongqing Medical University. The $\mathrm{CD} 4^{+}$cells were performed using Stemsep human CD34 positive selection cocktail and cultured in StemSpan serum-free expansion medium (Stem Cell Technologies, Canada) supplemented with $50 \mathrm{ng} / \mathrm{ml} \mathrm{SCF}, 10 \mathrm{ng} / \mathrm{ml} \mathrm{IL-6}$ and $10 \mathrm{ng} / \mathrm{ml} \mathrm{IL-3} \mathrm{(Pepro-}$ Tech, USA) at $37{ }^{\circ} \mathrm{C}$ in $5 \% \mathrm{CO}_{2}$. The study was approved by the ethical committee of Chongqing Medical University.

\section{Murine leukemogenesis model}

5-6 weeks old female NOD/SCID mice $(n=5$, each group) were selected and received 250 cGy radiation before injection. $2-4 \mathrm{~h}$ later, $5 \times 10^{6} \mathrm{~K} 562 / \mathrm{G} 01$ cells in $200 \mu \mathrm{l}$ PBS modified by ZFNs or treated with mock were injected intravenously. The weight change and white blood cells count of mice were monitored weekly. Weight loss, mental fatigue, splenomegaly and leukocyte hyperplasia were considered as the signs and symptoms of CML-like disease in mice.Peripheral blood was collected and incubated with the antibody against human CD45 to analyze the proportion of $\mathrm{CD} 45^{+}$cells by flow cytometry. All animal experiments were performed in accordance with the National Institutes of Health guide for the care and use of Laboratory animals (NIH

Table 1 Patient characteristics

\begin{tabular}{lll}
\hline Characteristics & Median (range) & No. of cases \\
\hline Gender & & 1 \\
Female & & 3 \\
Male & & 4 \\
Total & \\
Median age, y & $43.5 y(22-65 y)$ & \\
Median WBC, $\times 10^{9} / L$ & $216.97(112.3-399)$ & \\
Karyotype & \\
$\quad \mathrm{t}(9 ; 22)(q 34.1 ;$; 11.2$)$ & & 4 \\
\hline
\end{tabular}

Abbreviations: $y$ years old, WBC white blood cell
Publications No.8023, revised 1978) and were conducted with the approval of the Biomedical Ethics Committee of Chongqing Medical University.

\section{Statistical analysis}

Statistical analysis was performed using SPSS (Version 17.0) software. All data were expressed as the mean \pm SD. Student's test was used to assess the significant connections among categorical variables. $P<0.05$ was considered to be statistically significant.

\section{Results}

Construction of zinc finger nucleases and the homologous template donor DNA

The zinc finger nucleases (ZFNs) targeting exon 1 of the bcr-abl gene, which could cause a double-strand break (DSB), were designed and generated following modular assembly approach $[45,46]$. Both of the two zinc finger proteins (ZFPs) (designated ZFP-L and ZFP-R) arrays containing four zinc finger domains were assembled using an archive of ZFP DNA-binding modules [47, 48]. Each of ZFPs was coupled with a codon-optimized FokI domain containing mutations that can prevent homodimer formation and enhance the cleavage activity [30], which is termed as ZFN-L and ZFN-R respectively (Fig. 1a). A nuclear localization signal (NLS) was fused to ZFN and a FLAG tag was incorporated to N-terminal of the protein (Fig. 1b). The NLS allows transportation of ZFN protein to the nucleus binding to the targeted DNA. Our goal is to terminate the translation of BCRABL through the direct modification of bcr-abl gene sequence, so we built a suitable donor plasmid to trigger the HDR. The donor sequence containing a NotI site, which composed of 8-base, could result in the alteration of the open reading frame and the subsequently premature termination of translation (Fig. 1c).

\section{ZFN-mediated editing of bcr-abl gene and ending of BCR- $A B L$ protein translation}

The applications of gene editing by ZFNs are based on the generation of a site-specific DSB into the interesting sequence. Firstly, we analyzed the expression of ZFNs proteins. The nucleofected $\mathrm{K} 562$ cells were harvested at $0 \mathrm{~h}, 12 \mathrm{~h}, 24 \mathrm{~h}, 48 \mathrm{~h}$ and $96 \mathrm{~h}$. The result of western blot analysis showed the expression of ZFNs protein can be detected at $12 \mathrm{~h}$ after transfection, with a peak at $48 \mathrm{~h}$ and diminished at $72 \mathrm{~h}$ (Additional file 1: Figure S1A). To demonstrate the nuclear localization of the ZFNs proteins, cells were transfected with ZFN-L and ZFN-R plasmids, together or separately. After $48 \mathrm{~h}$, the amount of ZFNs proteins in the nucleus and cytoplasm were analyzed by western blot respectively. We demonstrated that the engineered ZFNs proteins could localized and expressed in nucleus (Additional file 1: Figure S1B). 


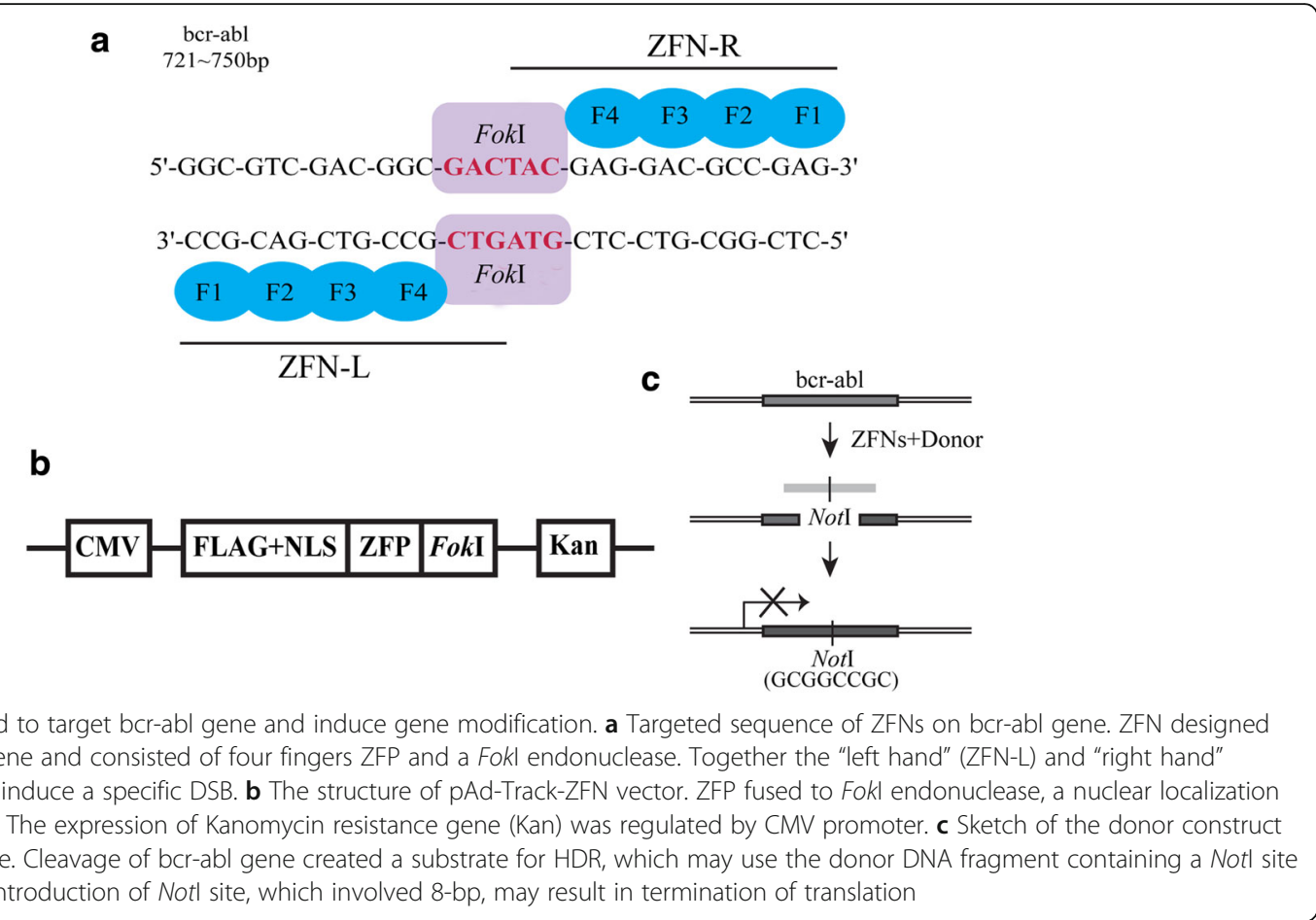

Next, to determine whether our ZFNs can introduce DSBs at exon 1 of bcr-abl gene, we transfected K562 cells with ZFN-L, ZFN-R separately or together. By detecting the p53-binding protein 1 (53BP1), which forms foci at DNA damage sites, we can evaluate the formation of DSBs by immunofluorescence [28]. Etoposide treated cells as positive control had a high level of 53BP1 foci (79.2\% > 3 foci). We observed a low level of 53BP1-stain foci in nontransduced or pAd-Track transduced $\mathrm{K} 562$ cells $(5.2 \%>3$ foci and $7.8 \%>3$ foci respectively) (Fig. 2a). Cells treated with ZFN-L or ZFN-R showed similar level of 53BP1-stain foci $(8.3 \%>3$ foci and $6.7 \%$ $>3$ foci respectively) (Additional file 2: Figure S2A). In contrast, a dramatic high level of 53BP1 foci $(56.9 \%>3$ foci) was observed in ZFN-L/R group (Fig. 2a). 53BP1 is recruited to the DSBs sites early in the DNA repair response and regarded as the hallmark of DSB. As shown above, ZFN-L/R can, and only can, cause DSBs in K562 cells. To further confirm this result, we analyzed another DNA damage marker, phosphorylated histone H2AX $(\gamma \mathrm{H} 2 \mathrm{AX})$ by western blot. As shown in Fig. 2b, compared with pAd-Track vector and $\mathrm{K} 562$ group, the expression of $\gamma \mathrm{H} 2 \mathrm{AX}$ was significantly increased in ZFN$L / R$ group and no significant difference was observed among other conditions (Additional file 2: Figure S2B). The detection of $\gamma \mathrm{H} 2 \mathrm{AX}$ expression further confirmed that the DSBs in K562 cells can be induced by ZFN-L/R. Together, these results demonstrate that ZFN-L/R induces DSBs in K562 cells.
Off-target DNA cleavage by ZFNs can be caused by the formation of homodimers between ZFN-L and ZFN-R [28, 29]. To avoid off-target effects, we adopted FokI nuclease variants that are restricted to form heterodimers as described above $[45,49]$. To evaluate the activity of ZFNs at the endogenous target sequence, T7 endonuclease I (T7E1) assay was carried out. A ZFNsinduced DSB is typically repaired by NHEJ, which often contains small insertions or deletions (called "indels") near the break site. The presence of indels in the K562 cells which treated by ZFNs, is confirmed by the mismatchsensitive T7E1. Then the percentage of bcr-abl gene modification (47.8\%) was quantified using gel imaging station (Fig. 2c). Moreover, genomic sequencing verified that the existence of various deletions and insertions resulting from NHEJ repair of the DSBs induced by activity of the ZFNs (Fig. 2d).

To determine whether the ZFNs and donor can mediate BCR-ABL translation termination, K562 cells were transfected with ZFN-L/R and donor, individually or together.

BCR-ABL translation termination, K562 cells were transfected with ZFN-L/R and donor, individually or together. After $48 \mathrm{~h}$, genomic DNA were collected and amplified by semiquantitative PCR followed by digestion with NotI restriction enzyme. HDR was observed in $60.14 \%$ of the bcr-abl gene (Fig. 2e). Genomic DNA cut by NotI was sequenced, results showed a stop codon and an end of translation near the DSB site (Fig. 2f). 
a

K562

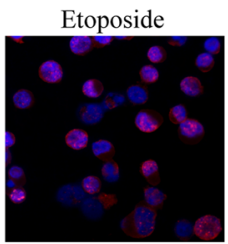

$79.2 \%>3$ foci

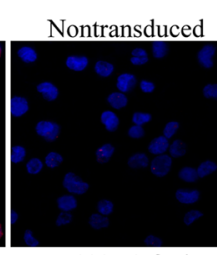

$5.2 \%>3$ foci
pAd-Track

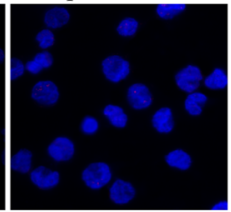

$7.8 \%>3$ foci
ZFN-L/R

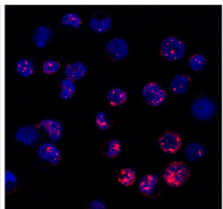

$56.9 \%>3$ foci b

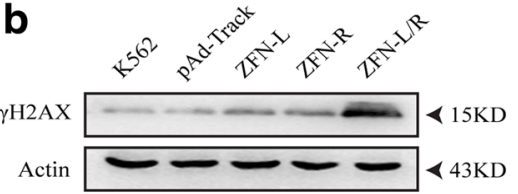

C

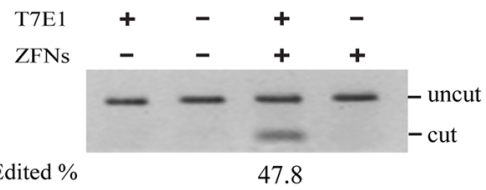

e

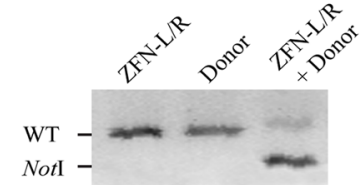

HDR \%

d

WT gagcagctgcggcgtcgacggcgactacgaggacgecgagttgaaccccc gagcagctgcgAcgtcgacggegactacgaggacgecgagttgaaccec gagcagctgcggGgtcgacggegactacgaggacgcegagttgaacecc gagcagctgcggcgtcgTcggcgactacgaggacgecgagttgaacccc gagcagctgcggegtcga Tggegactacgaggacgecgagttgaaccecc gagcagctgeggcgtcgac Agcgactacgaggacgecgagttgaaccccc gagcagetgeggegtcgacggeg Gctacgaggacgecgaottgaacecc gagcagctocogregtcoacogcoacCacoagracoccoagttgaaccccc (2) grac . gagcagctgcggcgtcgacggcgactacgaggacgecAagttgaaccccc gagcagctgcggegtcgacggegactacgaggacgecgag $\mathbf{C}$ tgaacccc gagcagctgcggcgtcgacggcgactacgaggacgecgagttgAaccecc gagcagctgeggcgtcgacggcgactacgagggcgecgagttgaa Tccec

WT gagcagctgcggegtcgacggcgactacgaggacgecgagttgaaccccc gagcagctgeggcgtcgacggc-actacgaggacgccgagttgaaccccc

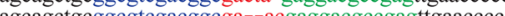
. gagcagetgeggeglegaege-

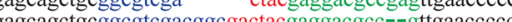
gagcagctgeg gtgacggectacgaggacgec- gttgaaccccc

$\mathbf{f}$

$$
\text { Wild type }
$$

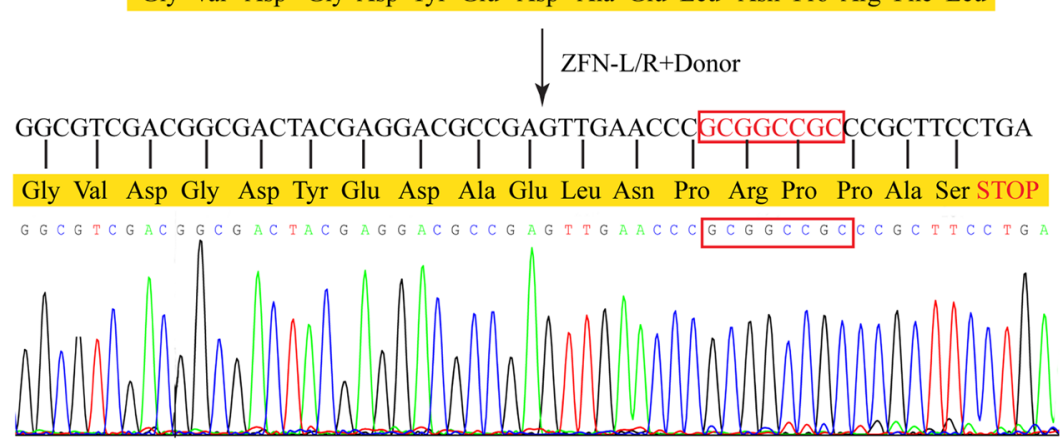

Fig. 2 ZFNs induced gene editing of bcr-abl gene. a K562 cells were treated with $1 \mu \mathrm{M}$ etoposide (positive control), pAd-Track or ZFN-L/R for $48 \mathrm{~h}$ and ZFNs-induced DSBs were detected by 53BP1 immunostaining. Nontransduced cells as negative control. The rate of cells containing more than 3 foci was shown beneath each panel. b K562 cells were transfected with pAd-Track, ZFN-L, ZFN-R plasmids separately or together of ZFN-L and ZFN-R (ZFN-L/R). The amount of $\mathrm{YH} 2 \mathrm{AX}$ in each group was quantified by western blot. The arrows indicate the marker proteins. $\mathbf{c}$ ZFNmediated gene editing revealed by T7E1 assay and the results indicated by agarose gel eletrophoresis. The bcr-abl was subjected to digestion with T7E1 to confirm the exist of insertions/deletions. Gene modification was only detected in cells transfected with ZFNs shown as 'cut' bands. d The genomic ZFNs target site in K562 cells was sequenced. The result showed the ZFN-induced insertions and deletions around the target region of bcr-abl. e The bcr-abl gene editing efficiency was quantified by Notl restriction enzyme. The genomic DNA of cells transfected with ZFN-L/R, Donor individually or together was extracted and amplified by PCR, then treated with Notl restriction enzyme. "WT" indicates the position of wild type PCR product and "Notl" indicates the position of the fragments generated by Notl digestion. Numbers below the lanes with Notl fragment indicate the rate of PCR product modification. $\mathbf{f}$ In silico analysis of sequence of ZFN-L/R and donor treated cells. The result showed the 8-bp (GCGGCCGC) insertion lead to a stop codon and a termination of translation 
ZFNs targeting bcr-abl depress the expression of BCR-ABL and its downstream signaling pathways

We performed western blot to confirm whether the ZFNs system can prevent BCR-ABL translation. In K562 and K562/G01 cells, the quantity of BCR-ABL and the activity of $\mathrm{p}-\mathrm{BCR}-\mathrm{ABL}$ in the group treated with donor and ZFN$\mathrm{L} / \mathrm{R}$ were significantly lower than that in groups of blank, ZFN-L, ZFN-R or Donor (Fig. 3a, Additional file 3: Figure $\mathrm{S} 3 \mathrm{~A})$. We noticed that there was still a few amount of $\mathrm{BCR}-\mathrm{ABL}$ expression, presumably because the restriction of plasmid transfection efficiency led to a small number of cells did not be edited (in our experiment, the efficiency of transfection of K562 cells can reach 93\%. Data not shown). Considering BCR-ABL activates multiple downstream pathways, we further measured key downstream proteins and found that the phosphorylation levels of STAT5, ERK and CRKL were decreased (Fig. 3b, Additional file 3: Figure S3B). Taken together, these results demonstrated that ZFNs targeting bcr-abl caused attenuation of BCR$\mathrm{ABL}$, accompanied with decreased phosphorylation of its downstream molecules including STAT5, ERK and CRKL.

ZFNs induce apoptosis and inhibit proliferation of CML cells To detect the effect of ZFNs on apoptosis of CML cells, we transfected K562 and K562/G01 cells with ZFN-L,
ZFN-R, Donor individually or together. Apoptosis was detected by flow cytometry and apoptotic rate significantly increased in donor and ZFN-L/R treated group compared to other groups (Fig. 4a, Additional file 4: Figure S4A). To confirm this effect, we visualized the nuclear morphology changes by DAPI staining. As shown in Fig. 4b, apoptosis characteristic morphological changes, such as condensed and fragmented nuclear, were observed in CML cells treated with ZFN-L/R and donor and no significant changes of nuclear morphology were observed in other groups (Additional file 4: Figure $\mathrm{S} 4 \mathrm{~B})$. The presence of BCR-ABL protein makes CML cells resistant to various apoptotic stimuli [50]. Cleaved caspase- 3 and PARP as the activation of caspase pathway were measured by western blotting. The result shown that caspase pathway activated in $\mathrm{K} 562$ and K562/G01 cells treated with donor and ZFN-L/R (Fig. 4c).

Next, we tested the influence of ZFNs on the proliferation of CML cells. Cell proliferation was measured by CCK- 8 assay and colony-forming assay. We found that, since the fourth day, the viability of donor and ZFN-L/R transfected cells was significantly lower than another groups. What's more, the CML cells in the group treated with donor and ZNF-L/R, from the first day to the fifth day, only had less proliferation (Fig. 4d). The result of

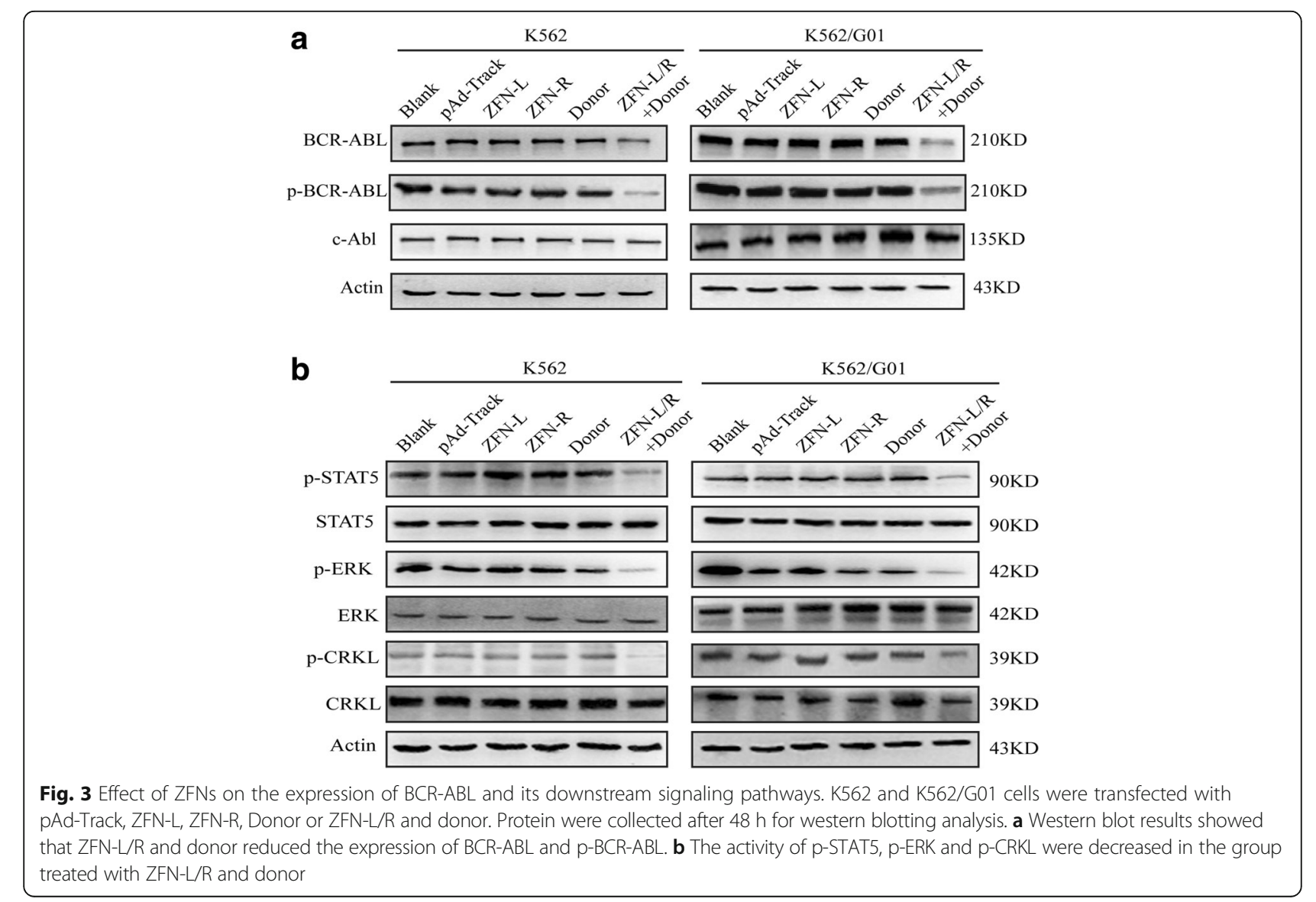



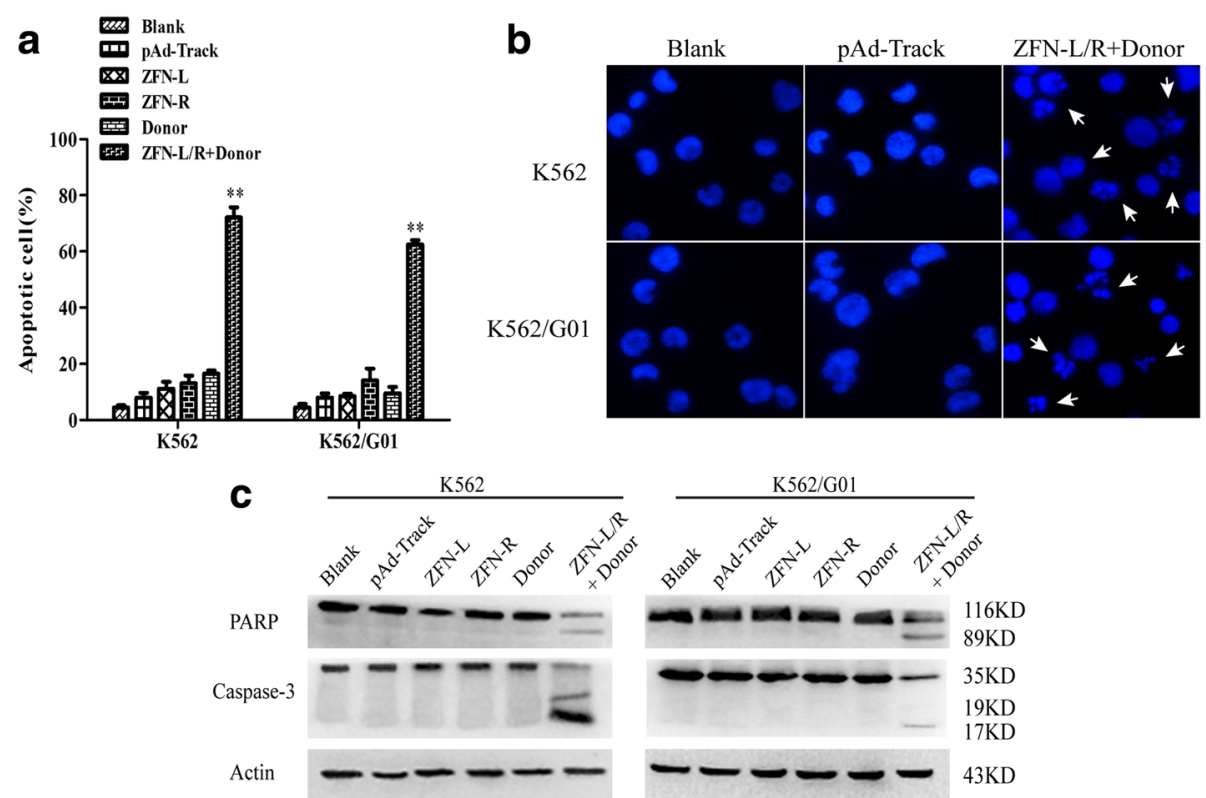

d
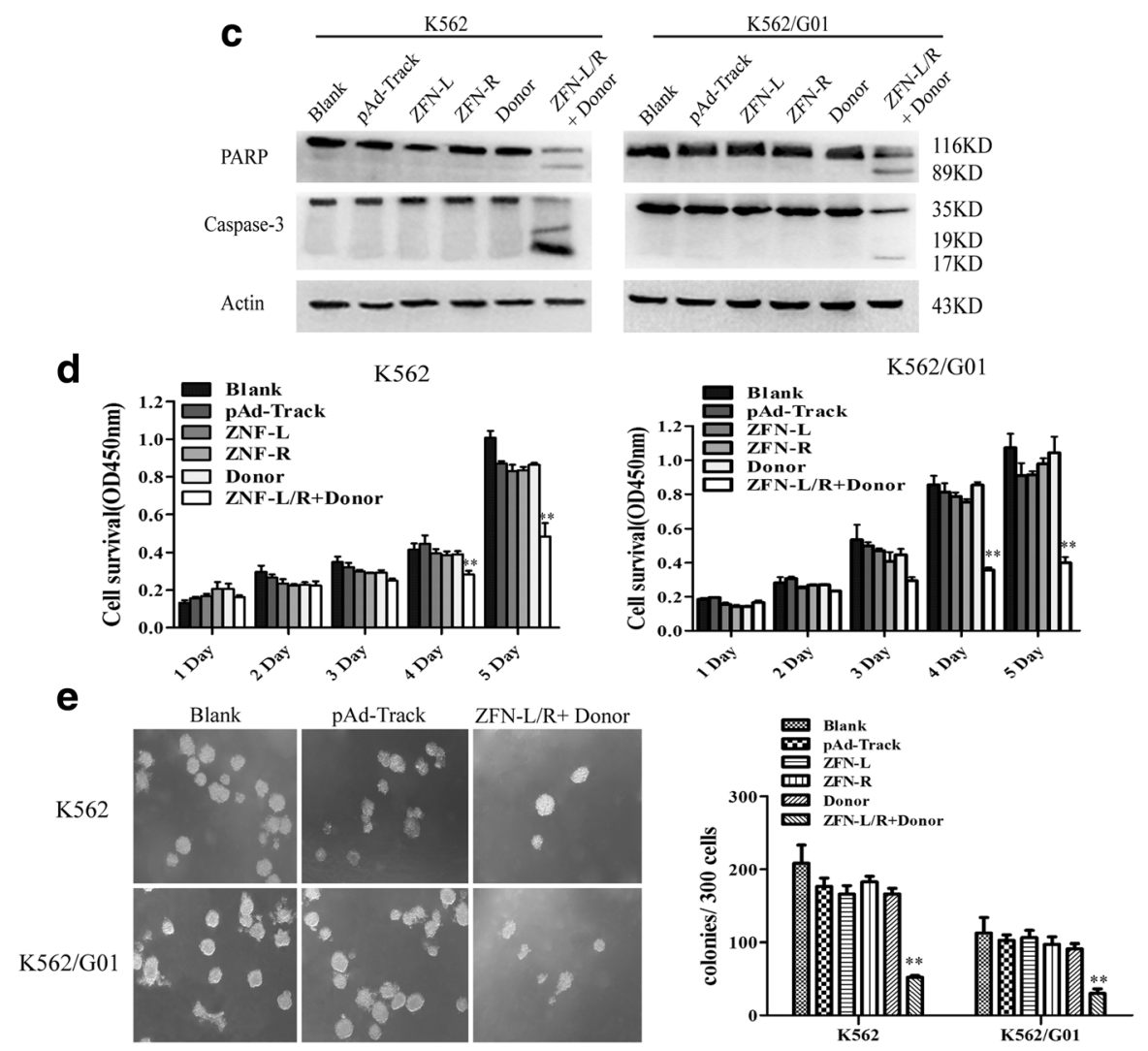

Fig. 4 ZFNs induces apoptosis and inhibits proliferation of CML cells. K562 and K562/G01 cells were respectively nucleofected with pAd-Track, ZFN-L, ZFN-R, Donor or ZFN-L/R and donor. a The percentage of cell apoptosis was detected by flow cytometry. $\mathbf{b}$ Morphologic changes of apoptotic cells were detected by DAPI stain. The arrows indicate the prominent apoptotic morphology. c Cleavage of PARP and Caspase-3 was detected by western blot. $\mathbf{d}$ The effect of ZFNs on CML cell proliferation was assessed by CCK-8 assay. e Treated cells were plated in 24-well plates with methylcellulose and colonies were counted after 2 weeks. Data are expressed as the means \pm SD. ${ }^{* *} P<0.01$ vs. Controls

colony-forming assay shown that donor and ZNF-L/R co-delivery also inhibited the colony formation ability of CML cells (Fig. 4e, Additional file 5: Figure S5A). Furthermore, to confirm whether the ZFNs system has cytotoxicity on bcr-abl negative cells, we transfected 32D, HepG2 and 293 T cells with the donor and ZFN-L/R expression plasmids and detected the proliferation using CCK- 8 assay. The results showed that no significant change was observed in these cells compared with untreated cells (Additional file 5: Figure S5B-D). These results indicated that co-delivery of donor and ZFN-L/R induced apoptosis and suppressed proliferation of imatinib sensitive and resistant CML cells.

ZFNs induce apoptosis and inhibit proliferation of primary CML leukemia stem/progenitor cells

To determine whether our ZFNs have effect on bcr-abl in primary leukemia stem/progenitor cells, we collected CD $34^{+}$cells from CML patients and transfected them with ZFN-L/R and donor. The efficiency of gene modification was measured by PCR-amplification followed by 
Not I digestion and agarose gel electrophoresis. These results showed that the combination of donor and ZFN-L/ $\mathrm{R}$ was able to induce gene editing in $\mathrm{CD} 34^{+}$cells from CML patients (Fig. 5a). Next, we detected the viability of modified cells by CCK- 8 assay and apoptosis through flow cytometry. ZFN-L/R and donor DNA significantly suppressed the proliferation and promoted the apoptosis of $\mathrm{CD}_{3} 4^{+}$cells from CML patients (Fig. 5b-f), but had no effect on $\mathrm{CD}_{3} 4^{+}$cells from bcr-abl negative patients who suffered from anemia (Additional file 6: Figure S6A-D).
ZFNs impair the pathogenicity of bcr-abl in vivo

In order to determine the effects of bcr-abl disruption by ZFNs in vivo, K562/G01 cells with treatments or no treatment were injected into NOD/SCID mice through tail vein. The treatments include transfection with pAdTrack, ZFN-L, ZFN-R, Donor or donor with ZFN-L/R. The white blood cell counts of mice in groups were monitored weekly and the peak number of each mouse was recorded. As shown in Fig. 6a, the peak level of leukocytes ZFN-L/R and donor treated mice reached was significantly lower when compared to other groups. To
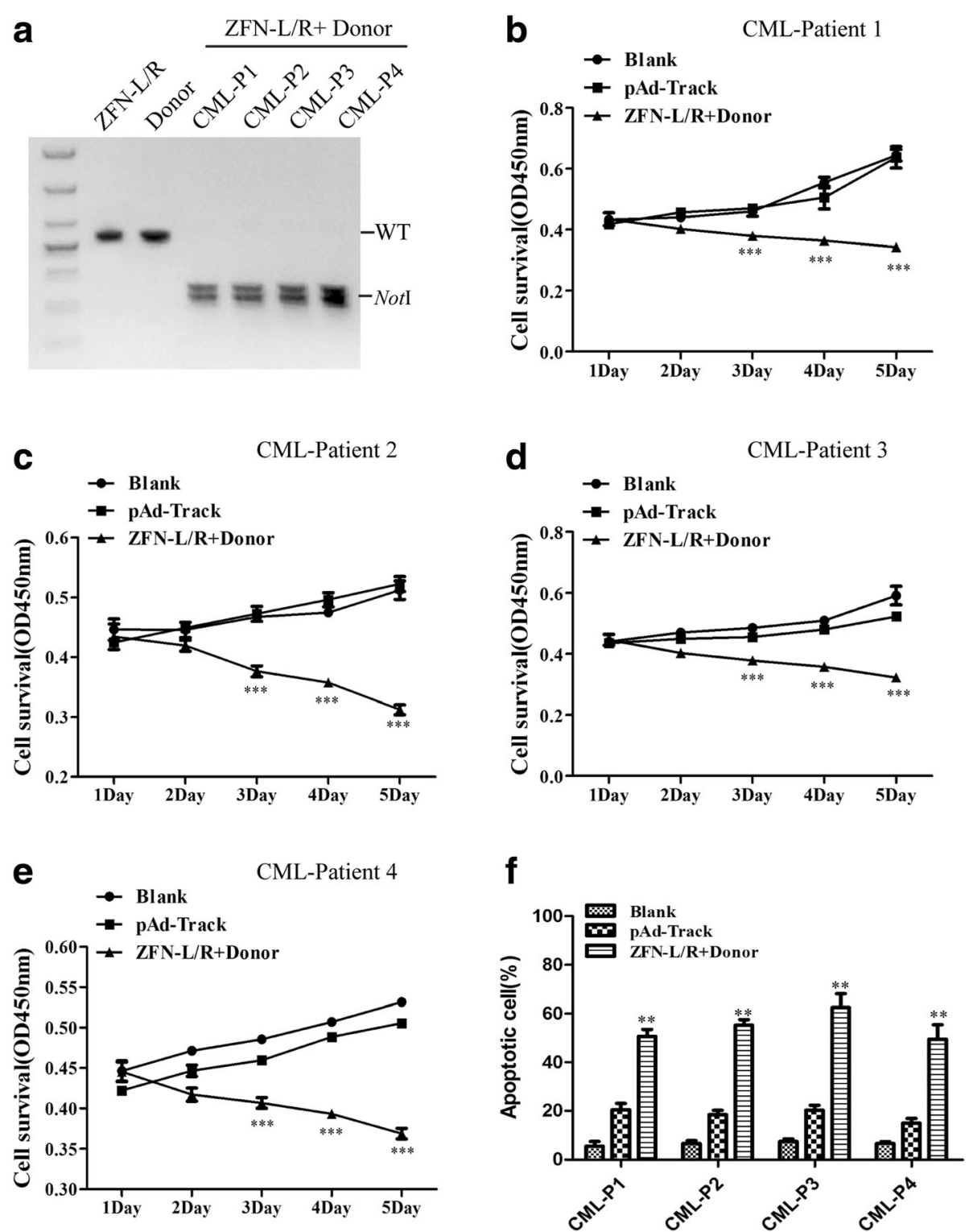

Fig. 5 ZFNs induces apoptosis and inhibits proliferation of $\mathrm{CD}_{3} 4^{+}$cells from CML patients. CML CD34 $4^{+}$cells were collected from patients and treated with ZFN-L/R and Donor plasmid, respectively or together. a The editing efficiency of ZFNs on bcr-abl gene editing was quantified by Notl restriction enzyme. CML-P1, CML-P2, CML-P3 and CML-P4 are abbreviations for CML-Patient 1, CML-Patient 2, CML-Patient 3 and CML-Patient 4 respectively. Cell viability was assessed via CCK8 assay $(\mathbf{b}),(\mathbf{c}),(\mathbf{d}),(\mathbf{e})$ and the percentage of apoptotic cells was determined by FCM (f). The data are shown as the mean \pm SD. ${ }^{* *} P<0.01$ vs. Controls and ${ }^{* *} P<0.001$ vs. Controls 


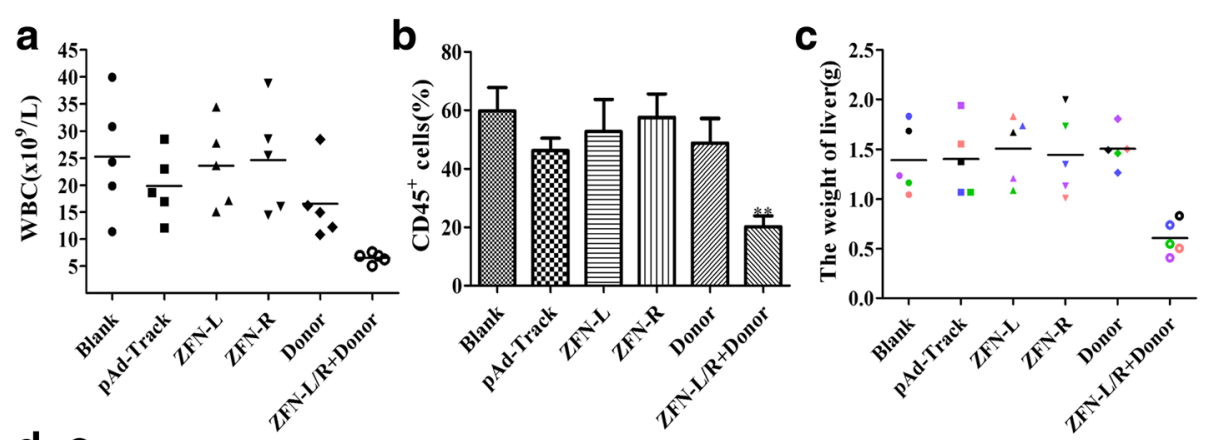

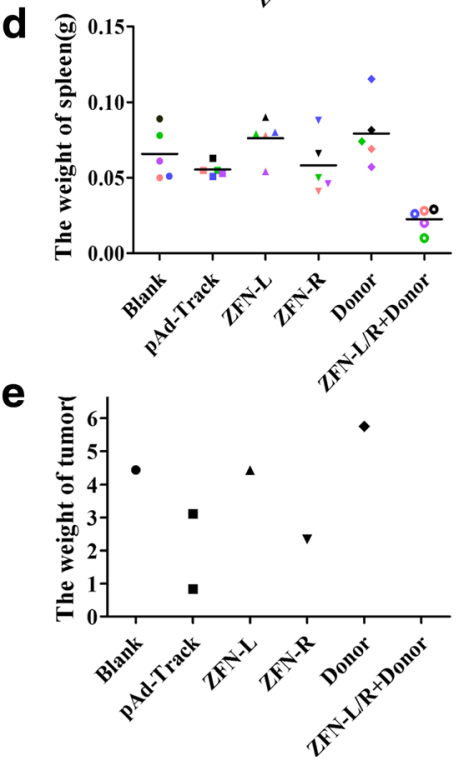

f

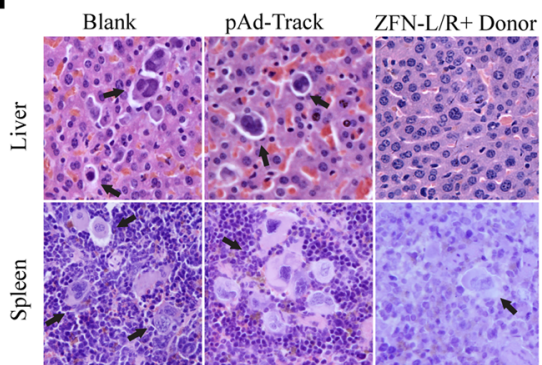

g

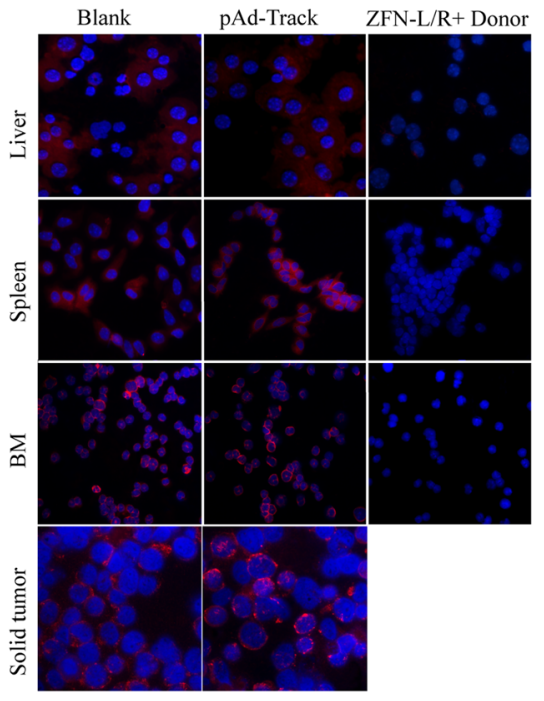

h

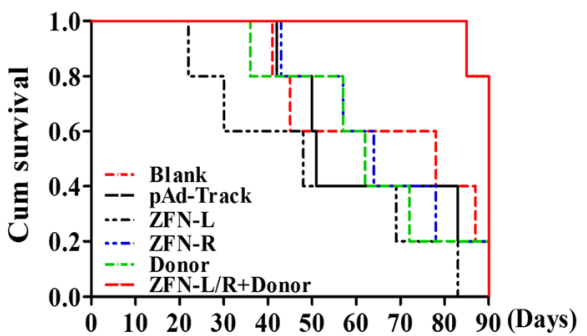

Fig. 6 ZFNs impairs the pathogenecity of bcr-abl in mice. a The maximum of WBC counts of each mouse in Blank, pAd-Track, ZFN-L, ZFN-R, Donor or ZFN-L/R and donor groups were recorded. $\mathbf{b}$ The rate of human $\mathrm{CD}_{4} 5^{+}$cells in murine bone marrow were detected by flow cytometry. $\mathbf{c}$, $\mathbf{d}$ Mean liver or spleen weight of mice in different group was quantified. e The weight of solid tumor for each groups were recorded. $\mathbf{f}$ Infiltration of liver or spleen in groups of Blank, pAd-Trackand or ZFN-L/R + donor was analysed by H\&E. The arrows indicate the infiltrating leukemic cells. $\mathbf{g}$ Detection of BCR-ABL protein by immunofluorescent assay infiltrating. $\mathbf{h}$ Survival curves were measured by Kaplan-Meier methods

confirm whether these leukocytes were leukemic or not, peripheral blood was collected from each group and CD45 antigen which expressed on the membrane surface of human leukocytes were detected by FCM. The number of CD45 positive cells indicated the number of K562/G01 cells propagating in murine bone marrow. As shown in Fig. 6b, the donor and ZFN-L/R group had lower level of CD45-positive cells than another groups. These results proved that ZFN-L/R and donor suppressed the proliferation of K562/G01 cells in NOD-
SCID mice. Furthermore, mice in group blank, ZFN-L, ZFN-R or Donor developed with more severe hepatomegaly and splenomegaly compared with ZFN-L/R and donor group (Fig. 6c-d, Additional file 7: Figure S7A). There was no mice harboring solid tumor in group treated with donor and ZFN-L/R. In contrast, in another groups there was one to two mice suffered from solid tumor in enterocoelia, buttock or cheek (Fig. 6e, Additional file 7: Figure S7B). Infiltration of leukemic cells in tissues was examined by hematoxylin/eosin (HE) 
and Wright's staining, and the BCR-ABL expression was detected via immunofluorescent. Mice treated with ZFN$\mathrm{L} / \mathrm{R}$ and donor were observed with less leukemic cell infiltration in the liver and spleen (Fig. 6f, Additional file 7: Figure S7C). By Wright's staining of bone marrow, a reduced Myeloid: Erythroid ratio was shown in ZFN-L/R and donor group when compared with other groups (Additional file 7: Figure S7D). Moreover, a high level expression of $\mathrm{BCR}-\mathrm{ABL}$ was detected in cells from livers, spleens, bone marrow or soild tumors from blank, ZFN-L, ZFN-R or Donor treated mice (Fig. $6 \mathrm{~g}$ or not shown). Kaplan-Meier survival analysis showed that the mice receiving ZFN-L/R and donor treated cells demonstrated significantly longer survival time than another groups (Fig. 6h). In summary, co-delivery of ZFN-L/R and donor was able to inhibit the proliferation and infiltration of K562/ G01 cells, ultimately, delay the onset of CML in mice.

\section{Discussion}

CML is a myeloproliferative neoplasm characterized by the $\mathrm{t}(9 ; 22)(\mathrm{q} 34 ; \mathrm{q} 11)$ reciprocal chromosomal translocation that generates the bcr-abl fusion gene encoding a constitutive kinase activity which is necessary for CML pathogenesis [51]. Imatinib has revolutionized CML therapy and remains the gold standard for the treatment, but more than $25 \%$ of patients will have drug resistance or intolerance [36]. The main cause of resistance to imatinib is the mutations in ABL kinase domain which impair the imatinib binding. The second-generation TKIs, such as nilotinib and dasatinib, retain inhibitory activity against the most of the mutations except the T315I "gatekeeper" mutation [52]. Although the third-generation TKI ponatinib exhibits inhibitory activity against all single mutations, its clinical use is limited by the severe side effects [13, 53, 54]. Besides, TKIs cannot eradicate leukemic stem cells (LSCs) of CML patients which would result in TKI-resistance or relapse [55-57]. Thus, the battle to effectively disrupt the pathological root of CML has been a long fight. In this study, we report a new strategy based on ZFNs editing bcr-abl gene at the protein-coding sequence and terminating the translation of $\mathrm{BCR}-\mathrm{ABL}$ to destroy the pathogenicity of imatinib sensitive and resistant CML cells in vivo and in vitro.

A successful application of ZFNs contains two important elements: specificity and efficiency. Firstly, high specificity depends on the two components of ZFN. With the progression over decades, the ZFP domain has developed into the engineered peptide being able to bind to almost any DNA sequence $[24,58,59]$. This region consists of $\mathrm{C}_{2} \mathrm{H}_{2}$-zinc fingers, each recognizing 3-bp of DNA. In general, three zinc fingers constitute the individual ZFNs to bind 9-bp targeting DNA. However, the 'three-finger' ZFNs had been confirmed with little activity and specificity [30]. Recent studies showed that more fingers of ZFNs (up to six per ZFN) can improved the specificity $[33,60,61]$. In our research, the ZFP designed with four fingers can recognize 12-bp DNA site and such a long site is rarer cleavage targets even in complex genomes. FokI dimerization is another important feature of ZFNs that only dimerized FokI domains can cleave DNA [62]. Moreover, to improve ZFNs specificity, we introduced the codon-optimized FokI domain which cleaves DNA only as a heterodimer pair. The 53BP1 was measured by immunostaining to monitor editing specificity of the ZFNs. We found that DSBs occurred highly above background only in K562 cells co-delivered with ZFN-L and ZFN-R (Fig. 2a-b).

Secondly, the efficiency of genome editing may be controlled by the DSB repair approach. NHEJ is more active than HDR in most of the cell cycle, which makes gene correction and insertion get more challenges [32]. However, when a homology donor DNA is delivered with ZFNs, the rate of HDR is dramatically enhanced at the DSB sites [27, 33, 34]. Based on this principle, ZFNdonor combination has been adopted to achieve efficient gene modification in various mammalian cells [27, 6367] and also applied to various diseases treatment [68, 69]. As we know, DSB repaired by NHEJ, an error-prone repair pathway, frequently inducing nucleotide indels in break site may lead to gene knockout. Nevertheless, the gene editing achieved by NHEJ is unpredictable and not all the indels are expected. In conclusion, co-delivery of ZFNs and donor can achieve efficient and user-designed gene editing by HDR repair pathway. Therefore, in this study, we tried to use HDR-driven gene modification for CML treatment.

To achieve therapeutic editing in clinical, the ZFNs need to be delivered to target cells, which can be performed either in vivo or ex vivo. In vivo genome editing therapy, the ZFNs are delivered directly to diseased cells in the body. This mode of therapy may have the potential to treat diseases that have effects on multiple organ systems. On the other hand, the appropriate vector [70-72], immune response [73] and unpredictable off-target [74] are the potential barriers for application of this therapy mode. In ex vivo therapy the target cells are removed from the body and transfused back into the host after modified with ZFNs. CML is suitable for ex vivo therapy with ZFNs. First, cells of hematopoietic system can survive under manipulated conditions outside the body. Second, in this study, our ZFNs system was capable of efficiently prevent the tumorigenesis potential of BCR-ABL (Figs. 3, $4,5)$. For ex vivo application, electroporation can be used to deliver plasmids of ZFNs into hematopoietic stem cells [75]. However, lentiviral vectors which may drive constitutive expression and more off-target activity are less desirable [32]. 
This is the first time to report a bcr-abl gene disruption approach based on ZFNs which may provide a novel therapeutic strategy for imatinib resistant or intolerant CML patients. The results of CCK- 8 assay, colony-forming assay and flow cytometry shown that the ZFNs had potent anti-leukemia ability in vitro. Also, we found that the ZFNs can impaired leukemogenesis of K562/G01 cells in mice by specifically targeting and disrupting bcr-abl gene. As we known, the point mutations in ABL kinase domain were responsible for TKIs resistance in CML patients [76], with this reason considered, we constructed ZFNs targeting BCR domain which also made the ZFNs suitable for treating drug-resistant patients with different mutations. In summary, the ZFNs technology may be the potential and effective method to treat CML.

\section{Conclusions}

The combination of donor and ZFNs demonstrated here is able to truncate BCR-ABL oncoprotein efficiently in CML cells and CML CD34 ${ }^{+}$cells and show the antileukemia ability in vitro and in vivo. This approach may provide a promising treatment choice for CML patients, especially for whom with imatinib resistance.

\section{Additional files}

Additional file 1: Figure S1. Expression of ZFNs proteins in K562 cells. (A) The proteins of K562 cells were collected after nucleofection of ZFNs at different times ( 0 to $72 \mathrm{~h}$ ). Anti-Flag antibody was used to detect the protein expression. (B) K562 cells were transfected with pAd-Track, ZFN-L, ZFN-R plasmids separately or together of ZFN-L and ZFN-R (ZFN-L/R). Nuclear and cytoplasmic proteins were collected, from which the amount of ZFN proteins were detected. The arrows indicate the marker proteins. Data are expressed as the means \pm SD. ${ }^{* *} P<0.01$ vs. Controls. (TIFF $511 \mathrm{~kb}$ )

Additional file 2: Figure S2. Supporting data for Fig. 2. (A) K562 cells were treated with ZFN-L and ZFN-R for $48 \mathrm{~h}$ and ZFNs-induced DSBs detected by $53 \mathrm{BP} 1$ immunostaining. The rate of cells containing more than 3 foci was shown beneath each panel. (B) Quantification of $\mathrm{YH} 2 \mathrm{AX}$ protein from the experiments, normalized to actin. The data are shown as the mean \pm SD. ${ }^{* *} P<0.01$ vs. Controls. (TIFF $327 \mathrm{~kb}$ )

Additional file 3: Figure S3. Supporting data for Fig. 3. (A), (B) Quantification of protein from the experiments, normalized to actin. The data are shown as the mean \pm SD. ${ }^{* *} P<0.01$ vs. Controls. (TIFF $745 \mathrm{~kb}$ )

Additional file 4: Figure S4. Supporting data for Fig. 4. (A) The percentage of apoptotic cells was determined by 7-AAD/AnnexinV-PE staining followed by flow cytometric analysis. (B) K562 and K562/G01 cells were treated with ZFN-L, ZFN-R or Donor. The morphologic changes of apoptotic cells were detected by DAPI stain (TIFF $1504 \mathrm{~kb}$ )

Additional file 5: Figure S5. Supporting data for Fig. 4. (A) The colony formation ability of K562 and K562/G01 cells which treated with ZFN-L, ZFN-R or Donor. (B), (C), (D) The viability of 32D, HepG2 and 293 T cells treated with pAd-Track or ZFN-L/R and donor was measured by CCK-8 assay. (TIFF $1102 \mathrm{~kb}$ )

Additional file 6: Figure S6. ZFNs have no effect on the proliferation and apoptotic rate of $\mathrm{CD} 34^{+}$cells from anemia patients. CD34 $4^{+}$cells were collected from anemia patients and treated with ZFN-L/R and Donor plasmid, respectively or together. (A), (B), (C) Cell viability was assessed via CCK8 assay. (D) The percentage of apoptotic cells was determined by FCM. (TIFF $424 \mathrm{~kb}$ )
Additional file 7: Figure S7. Supporting data for Fig. 6. (A) Representative images of livers and spleens from groups of Blank, pAd-Track, ZFN-L, ZFN-R, Donor or ZFN-L/R and donor. (B) Comparison of the size of solid tumor from each groups. (C) Infiltration of liver and spleen in group of ZFN-L, ZFN-R and Donor was analysed by H\&E. The arrows indicate the infiltrating leukemic cells. (D) Bone marrow cells from mice in each group were stained with Wright's staining. The arrows indicate the typical leukemic cells. (TIFF 4194 kb)

\section{Abbreviations}

CML: Chronic myeloid leukemia; DSB: Double strand break; FCM: Flow cytometry; HDR: Homology-directed repair; HE: Hematoxylin/eosin; indels: Insertions or deletions; LSCs: Leukemic stem cells; NHEJ: Nonhomologous end joining; NLS: Nuclear localization signal; T7E1: T7 endonuclease 1; TKI: Tyrosine kinase inhibitor; WBC: White blood cells; ZFNs: Zinc finger nucleases; ZFPs: Zinc finger proteins

\section{Acknowledgements}

Not applicable.

\section{Funding}

This work was supported by the National Natural Science Foundation of China (No.81572060 and No.81500129), Research and Cultivation Fund Project of Chongqing Medical University (No.201415), Scientific and Technological Research Program of Chongqing Municipal Education Commission (No.KJ1500215) and Chongqing Postgraduate Research and innovation project (No.CYS15120 and No.CYS16136).

\section{Availability of data and materials}

All data generated or analyzed during this study are included in this published article and raw data are stored in corresponding author and are available upon request.

\section{Authors' contributions}

NSH, MG conceived and designed the experiments. NSH, ZHL performed the experiments and wrote the paper. ZLH provide assistance with revising the manuscript. FZZ collected and analyzed the data. LL, QX, XW prepared the patient samples. WLF supervised the experimental work and revised critically the manuscript. All authors read and approved the final manuscript.

\section{Ethics approval and consent to participate}

All samples were collected with informed consent and all the experiment were approved by the ethical committee. All animal experiments were in accordance with the National Institutes of Health guide for the care and use of Laboratory animals (NIH Publications No. 8023, revised 1978) and were conducted with the approval of the Biomedical Ethics Committee of Chongqing Medical University.

\section{Consent for publication}

Not applicable.

\section{Competing interests}

The authors declare that they have no competing interests.

\section{Publisher's Note}

Springer Nature remains neutral with regard to jurisdictional claims in published maps and institutional affiliations.

\section{Author details}

'Department of Clinical Hematology, Key Laboratory of Laboratory Medical Diagnostics Designated by the Ministry of Education, Chongqing Medical University, No.1, Yixueyuan Road, Chongqing 400016, People's Republic of China. ${ }^{2}$ Department of Laboratory Medicine, The First Affiliated Hospital of Chongqing Medical University, Chongqing 400016, People's Republic of China. ${ }^{3}$ Department of Hematology, The First Affiliated Hospital, Chongqing Medical University, Chongqing 400016, People's Republic of China. 


\section{Received: 28 January 2018 Accepted: 12 March 2018} Published online: 20 March 2018

\section{References}

1. Druker BJ. Translation of the Philadelphia chromosome into therapy for CML. Blood. 2008;112:4808-17.

2. Heisterkamp N, Stephenson JR, Groffen J, Hansen PF, de Klein A, Bartram CR, Grosveld G. Localization of the c-ab1 oncogene adjacent to a translocation break point in chronic myelocytic leukaemia. Nature. 1983;306:239-42.

3. Ben-Neriah Y, Daley GQ, Mes-Masson AM, Witte ON, Baltimore D. The chronic myelogenous leukemia-specific P210 protein is the product of the bcr/abl hybrid gene. Science. 1986;233:212-4.

4. Lugo TG, Pendergast AM, Muller AJ, Witte ON. Tyrosine kinase activity and transformation potency of bcr-abl oncogene products. Science. 1990;247: 1079-82.

5. Steelman LS, Pohnert SC, Shelton JG, Franklin RA, Bertrand FE, McCubrey JA JAK/STAT, Raf/MEK/ERK, PI3K/Akt and BCR-ABL in cell cycle progression and leukemogenesis. Leukemia. 2004;18:189-218.

6. Druker BJ, Tamura S, Buchdunger E, Ohno S, Segal GM, Fanning S, Zimmermann J, Lydon NB. Effects of a selective inhibitor of the Abl tyrosine kinase on the growth of Bcr-Abl positive cells. Nat Med. 1996;2:561-6.

7. Druker BJ, Guilhot F, O'Brien SG, Gathmann I, Kantarjian H, Gattermann N, Deininger MW, Silver RT, Goldman JM, Stone RM, et al. Five-year follow-up of patients receiving imatinib for chronic myeloid leukemia. N Engl J Med. 2006;355:2408-17

8. Steegmann JL, Baccarani M, Breccia M, Casado LF, Garcia-Gutierrez V, Hochhaus A, Kim DW, Kim TD, Khoury HJ, Le Coutre P, et al. European LeukemiaNet recommendations for the management and avoidance of adverse events of treatment in chronic myeloid leukaemia. Leukemia. 2016; 30:1648-71.

9. Shah NP, Tran C, Lee FY, Chen P, Norris D, Sawyers CL. Overriding imatinib resistance with a novel ABL kinase inhibitor. Science. 2004;305:399-401.

10. Efficace F, Baccarani M, Breccia M, Alimena G, Rosti G, Cottone F, Deliliers GL, Barate C, Rossi AR, Fioritoni G, et al. Health-related quality of life in chronic myeloid leukemia patients receiving long-term therapy with imatinib compared with the general population. Blood. 2011;118:4554-60.

11. Caldemeyer L, Dugan M, Edwards J, Akard L. Long-term side effects of tyrosine kinase inhibitors in chronic myeloid leukemia. Curr Hematol Malig Rep. 2016;11:71-9.

12. Hadzijusufovic E, Albrecht-Schgoer K, Huber K, Hoermann G, Grebien F, Eisenwort G, Schgoer W, Herndlhofer S, Kaun C, Theurl M, et al. Nilotinibinduced vasculopathy: identification of vascular endothelial cells as a primary target site. Leukemia. 2017;31:2388-97

13. Alloo A, Sheu J, Butrynski JE, DeAngelo DJ, George S, Murphy GF, LeBoeuf NR. Ponatinib-induced pityriasiform, folliculocentric and ichthyosiform cutaneous toxicities. Br J Dermatol. 2015:173:574-7.

14. Bibikova M, Beumer K, Trautman JK, Carroll D. Enhancing gene targeting with designed zinc finger nucleases. Science. 2003;300:764.

15. Bibikova M, Golic M, Golic KG, Carroll D. Targeted chromosomal cleavage and mutagenesis in Drosophila using zinc-finger nucleases. Genetics. 2002; 161:1169-75.

16. Smith J, Bibikova M, Whitby FG, Reddy AR, Chandrasegaran S, Carroll D. Requirements for double-strand cleavage by chimeric restriction enzymes with zinc finger DNA-recognition domains. Nucleic Acids Res. 2000;28: 3361-9.

17. Boch J, Scholze H, Schornack S, Landgraf A, Hahn S, Kay S, Lahaye T, Nickstadt A, Bonas U. Breaking the code of DNA binding specificity of TALtype III effectors. Science. 2009;326:1509-12.

18. Christian M, Cermak T, Doyle EL, Schmidt C, Zhang F, Hummel A, Bogdanove AJ, Voytas DF. Targeting DNA double-strand breaks with TAL effector nucleases. Genetics. 2010;186:757-61.

19. Li T, Huang S, Jiang WZ, Wright D, Spalding MH, Weeks DP, Yang B. TAL nucleases (TALNs): hybrid proteins composed of TAL effectors and Fokl DNA-cleavage domain. Nucleic Acids Res. 2011;39:359-72.

20. Barrangou R, Fremaux C, Deveau H, Richards M, Boyaval P, Moineau S, Romero DA, Horvath P. CRISPR provides acquired resistance against viruses in prokaryotes. Science. 2007;315:1709-12.

21. Garneau JE, Dupuis ME, Villion M, Romero DA, Barrangou R, Boyaval P, Fremaux C, Horvath P, Magadan AH, Moineau S. The CRISPR/Cas bacterial immune system cleaves bacteriophage and plasmid DNA. Nature. 2010;468: $67-71$.
22. Kim YG, Cha J, Chandrasegaran S. Hybrid restriction enzymes: zinc finger fusions to Fok I cleavage domain. Proc Natl Acad Sci U S A. 1996;93: 1156-60.

23. Smith J, Berg JM, Chandrasegaran S. A detailed study of the substrate specificity of a chimeric restriction enzyme. Nucleic Acids Res. 1999;27: 674-81.

24. Pavletich NP, Pabo CO. Zinc finger-DNA recognition: crystal structure of a Zif268-DNA complex at 2.1 a. Science. 1991;252:809-17.

25. Klug A. Co-chairman's remarks: protein designs for the specific recognition of DNA. Gene. 1993;135:83-92.

26. Durai S, Mani M, Kandavelou K, Wu J, Porteus MH, Chandrasegaran S. Zinc finger nucleases: custom-designed molecular scissors for genome engineering of plant and mammalian cells. Nucleic Acids Res. 2005;33: 5978-90.

27. Urnov FD, Miller JC, Lee YL, Beausejour CM, Rock JM, Augustus S, Jamieson AC, Porteus MH, Gregory PD, Holmes MC. Highly efficient endogenous human gene correction using designed zinc-finger nucleases. Nature. 2005; 435:646-51

28. Miller JC, Holmes MC, Wang J, Guschin DY, Lee YL, Rupniewski I, Beausejour CM, Waite AJ, Wang NS, Kim KA, et al. An improved zinc-finger nuclease architecture for highly specific genome editing. Nat Biotechnol. 2007;25: $778-85$

29. Szczepek M, Brondani V, Buchel J, Serrano L, Segal DJ, Cathomen T. Structure-based redesign of the dimerization interface reduces the toxicity of zinc-finger nucleases. Nat Biotechnol. 2007;25:786-93.

30. Perez-Pinera P, Ousterout DG, Brown MT, Gersbach CA. Gene targeting to the ROSA26 locus directed by engineered zinc finger nucleases. Nucleic Acids Res. 2012:40:3741-52.

31. Jackson SP, Bartek J. The DNA-damage response in human biology and disease. Nature. 2009:461:1071-8.

32. Cox DB, Platt RJ, Zhang F. Therapeutic genome editing: prospects and challenges. Nat Med. 2015;21:121-31.

33. Urnov FD, Rebar EJ, Holmes MC, Zhang HS, Gregory PD. Genome editing with engineered zinc finger nucleases. Nat Rev Genet. 2010;11:636-46.

34. Porteus MH, Baltimore D. Chimeric nucleases stimulate gene targeting in human cells. Science. 2003:300:763.

35. O'Driscoll M, Jeggo PA. The role of double-strand break repair - insights from human genetics. Nat Rev Genet. 2006;7:45-54

36. Segal DJ, Beerli RR, Blancafort P, Dreier B, Effertz K, Huber A, Koksch B, Lund $C V$, Magnenat $L$, Valente $D$, et al. Evaluation of a modular strategy for the construction of novel polydactyl zinc finger DNA-binding proteins. Biochemistry. 2003;42:2137-48.

37. Kim HJ, Lee HJ, Kim H, Cho SW, Kim JS. Targeted genome editing in human cells with zinc finger nucleases constructed via modular assembly. Genome Res. 2009;19:1279-88.

38. Maru Y, Witte ON. The BCR gene encodes a novel serine/threonine kinase activity within a single exon. Cell. 1991;67:459-68.

39. McWhirter JR, Galasso DL, Wang JY. A coiled-coil oligomerization domain of $\mathrm{Bcr}$ is essential for the transforming function of Bcr-Abl oncoproteins. Mol Cell Biol. 1993;13:7587-95.

40. Pendergast AM, Quilliam LA, Cripe LD, Bassing CH, Dai Z, Li N, Batzer A Rabun KM, Der CJ, Schlessinger J, et al. BCR-ABL-induced oncogenesis is mediated by direct interaction with the $\mathrm{SH} 2$ domain of the GRB-2 adaptor protein. Cell. 1993;75:175-85.

41. Pendergast AM, Muller AJ, Havlik MH, Maru Y, Witte ON. BCR sequences essential for transformation by the BCR-ABL oncogene bind to the $A B L S H 2$ regulatory domain in a non-phosphotyrosine-dependent manner. Cell. 1991; 66:161-71.

42. Zhu HL, Liu T, Meng WT, Jia YQ. Establishment of an imatinib resistance cell line K562R and its resistant principia. Sichuan da xue xue bao Yi xue ban = J of Sichuan University Med Sci Ed. 2007;38:22-6.

43. Pellagatti A, Roy S, Di Genua C, Burns A, McGraw K, Valletta S, Larrayoz MJ Fernandez-Mercado M, Mason J, Killick S, et al. Targeted resequencing analysis of 31 genes commonly mutated in myeloid disorders in seria samples from myelodysplastic syndrome patients showing disease progression. Leukemia. 2016;30:247-50.

44. Li H, Huang Z, Gao M, Huang N, Luo Z, Shen H, Wang X, Wang T, Hu J, Feng $W$. Inhibition of YAP suppresses CML cell proliferation and enhances efficacy of imatinib in vitro and in vivo. J Exp Clin Cancer Res. 2016;35:134.

45. Mandell JG, Barbas CF 3rd. Zinc finger tools: custom DNA-binding domains for transcription factors and nucleases. Nucleic Acids Res. 2006;34:W516-23. 
46. Gonzalez B, Schwimmer LJ, Fuller RP, Ye Y, Asawapornmongkol L, Barbas CF 3rd. Modular system for the construction of zinc-finger libraries and proteins. Nat Protoc. 2010;5:791-810.

47. Moore M, Choo Y, Klug A. Design of polyzinc finger peptides with structured linkers. Proc Natl Acad Sci U S A. 2001;98:1432-6.

48. Jamieson AC, Miller JC, Pabo CO. Drug discovery with engineered zincfinger proteins. Nat Rev Drug Discov. 2003;2:361-8.

49. Doyon Y, Vo TD, Mendel MC, Greenberg SG, Wang J, Xia DF, Miller JC Urnov FD, Gregory PD, Holmes MC. Enhancing zinc-finger-nuclease activity with improved obligate heterodimeric architectures. Nat Methods. 2011;8: 74-9.

50. Wang F, Dai AY, Tao K, Xiao Q, Huang ZL, Gao M, Li H, Wang X, Cao WX, Feng WL. Heat shock protein-70 neutralizes apoptosis inducing factor in Bcr/Abl expressing cells. Cell Signal. 2015;27:1949-55.

51. Ren R. Mechanisms of BCR-ABL in the pathogenesis of chronic myelogenous leukaemia. Nat Rev Cancer. 2005;5:172-83.

52. Eide CA, O'Hare T. Chronic myeloid leukemia: advances in understanding disease biology and mechanisms of resistance to tyrosine kinase inhibitors. Curr Hematol Malig rep. 2015;10:158-66.

53. O'Hare T, Shakespeare WC, Zhu X, Eide CA, Rivera VM, Wang F, Adrian LT, Zhou T, Huang WS, Xu Q, et al. AP24534, a pan-BCR-ABL inhibitor for chronic myeloid leukemia, potently inhibits the T315I mutant and overcomes mutation-based resistance. Cancer Cell. 2009;16:401-12.

54. Small S. Marketing and commercial distribution of ponatinib suspended following FDA request. Clin Adv Hematol Oncol. 2013;11:808-9.

55. Weisberg E, Manley PW, Cowan-Jacob SW, Hochhaus A, Griffin JD. Second generation inhibitors of $B C R-A B L$ for the treatment of imatinib-resistant chronic myeloid leukaemia. Nat Rev Cancer. 2007;7:345-56.

56. Graham SM, Jorgensen HG, Allan E, Pearson C, Alcorn MJ, Richmond L, Holyoake TL. Primitive, quiescent, Philadelphia-positive stem cells from patients with chronic myeloid leukemia are insensitive to STI571 in vitro. Blood. 2002;99:319-25.

57. Chomel JC, Bonnet ML, Sorel N, Sloma I, Bennaceur-Griscelli A, Rea D, Legros L, Marfaing-Koka A, Bourhis JH, Ame S, et al. Leukemic stem cell persistence in chronic myeloid leukemia patients in deep molecular response induced by tyrosine kinase inhibitors and the impact of therapy discontinuation. Oncotarget. 2016;7:35293-301.

58. Pabo CO, Peisach E, Grant RA. Design and selection of novel Cys2His2 zinc finger proteins. Annu Rev Biochem. 2001;70:313-40.

59. Choo Y, Klug A. Physical basis of a protein-DNA recognition code. Curr Opin Struct Biol. 1997;7:117-25.

60. Gordley RM, Gersbach CA, Barbas CF 3rd. Synthesis of programmable integrases. Proc Natl Acad Sci U S A. 2009;106:5053-8.

61. Gersbach CA, Gaj T, Gordley RM, Barbas CF 3rd. Directed evolution of recombinase specificity by split gene reassembly. Nucleic Acids Res. 2010;38: 4198-206.

62. Vanamee ES, Santagata S, Aggarwal AK. Fokl requires two specific DNA sites for cleavage. J Mol Biol. 2001;309:69-78.

63. Lombardo A, Genovese P, Beausejour CM, Colleoni S, Lee YL, Kim KA, Ando D, Urnov FD, Galli C, Gregory PD, et al. Gene editing in human stem cells using zinc finger nucleases and integrase-defective lentiviral vector delivery. Nat Biotechnol. 2007;25:1298-306.

64. Moehle EA, Rock JM, Lee YL, Jouvenot Y, DeKelver RC, Gregory PD, Urnov FD, Holmes MC. Targeted gene addition into a specified location in the human genome using designed zinc finger nucleases. Proc Natl Acad Sci U S A. 2007;104:3055-60.

65. Hockemeyer D, Soldner F, Beard C, Gao Q, Mitalipova M, DeKelver RC Katibah GE, Amora R, Boydston EA, Zeitler B, et al. Efficient targeting of expressed and silent genes in human ESCS and iPSCs using zinc-finger nucleases. Nat Biotechnol. 2009;27:851-7.

66. Dekelver RC, Choi VM, Moehle EA, Paschon DE, Hockemeyer D, Meijsing SH, Sancak Y, Cui X, Steine EJ, Miller JC, et al. Functional genomics, proteomics, and regulatory DNA analysis in isogenic settings using zinc finger nucleasedriven transgenesis into a safe harbor locus in the human genome. Genome Res. 2010;20:1133-42.

67. Cui $X$, Ji D, Fisher DA, Wu Y, Briner DM, Weinstein EJ. Targeted integration in rat and mouse embryos with zinc-finger nucleases. Nat Biotechnol. 2011;29: 64-7.

68. Genovese P, Schiroli G, Escobar G, Tomaso TD, Firrito C, Calabria A, Moi D, Mazzieri R, Bonini C, Holmes MC, et al. Targeted genome editing in human repopulating haematopoietic stem cells. Nature. 2014;510:235-40.
69. Li H, Haurigot V, Doyon Y, Li T, Wong SY, Bhagwat AS, Malani N, Anguela XM, Sharma $R$, Ivanciu $L$, et al. In vivo genome editing restores haemostasis in a mouse model of haemophilia. Nature. 2011;475:217-21.

70. Kotterman MA, Schaffer DV. Engineering adeno-associated viruses for clinical gene therapy. Nat Rev Genet. 2014;15:445-51.

71. Nguyen TH, Ferry N. Liver gene therapy: advances and hurdles. Gene Ther. 2004;11(Suppl 1):S76-84

72. Boye SE, Boye SL, Lewin AS, Hauswirth WW. A comprehensive review of retinal gene therapy. Mol Ther. 2013;21:509-19.

73. Bessis N, GarciaCozar FJ, Boissier MC. Immune responses to gene therapy vectors: influence on vector function and effector mechanisms. Gene Ther. 2004;11(Suppl 1):S10-7.

74. Yin H, Kanasty RL, Eltoukhy AA, Vegas AJ, Dorkin JR, Anderson DG. Non-viral vectors for gene-based therapy. Nat Rev Genet. 2014;15:541-55.

75. Gaj T, Guo J, Kato Y, Sirk SJ, Barbas CF 3rd. Targeted gene knockout by direct delivery of zinc-finger nuclease proteins. Nat Methods. 2012;9:805-7.

76. Soverini S, Martinelli G, Rosti G, Bassi S, Amabile M, Poerio A, Giannini B, Trabacchi E, Castagnetti F, Testoni N, et al. ABL mutations in late chronic phase chronic myeloid leukemia patients with up-front cytogenetic resistance to imatinib are associated with a greater likelihood of progression to blast crisis and shorter survival: a study by the GIMEMA working party on chronic myeloid leukemia. J Clin Oncol. 2005;23:4100-9.

\section{Submit your next manuscript to BioMed Central and we will help you at every step:}

- We accept pre-submission inquiries

- Our selector tool helps you to find the most relevant journal

- We provide round the clock customer support

- Convenient online submission

- Thorough peer review

- Inclusion in PubMed and all major indexing services

- Maximum visibility for your research

Submit your manuscript at www.biomedcentral.com/submit
Biomed Central 